\title{
Farmer Gone Fish'n? Swidden Decline and the Rise of Grouper Fishing on Palawan Island, the Philippines
}

\author{
WOLFRAM H. DRESSLER AND MICHAEL FABINYI
}

\begin{abstract}
Considerable research has focused on understanding how upland farmers adjust land-based livelihoods to the influences of agrarian change in Southeast Asia. In the process, an 'upland bias' has emerged where researchers focus narrowly on the uplands as localities with distinct, coherent features, neglecting how families engage place, social relations and ethnicity as they access opportunities in proximate spaces. This paper considers how the Tagbanua - long considered an upland swidden people - have 'stepped back' from swidden agriculture due to declining yields and debt to harvest the lucrative grouper (e.g. Plectropomus leopardus). We show how Tagbanua families on Palawan Island have adjusted swidden as they negotiate social relations, ethnic cleavages and economic barriers to effectively engage the grouper industry. Rather than cast such farmers and fishers as ideal types in place, we argue that how they negotiate social relations creates new livelihood opportunities in varied environments, reinforcing the dynamic, recursive context of agrarian change.
\end{abstract}

Keywords: agrarian change, Philippines, swidden, fishing, human geography

\section{INTRODUCTION}

Global economic change has been driving the contemporary 'agrarian transition' in Southeast Asia - a process whereby national and local economies move from being predominantly agricultural and rural to predominantly industrial and urban (Tomich et al. 1995; Bryceson 1996; Elson 1997; Patel 2006; Cramb et al. 2009). Interconnected capitalist markets, privatesector investments and commodity supply chains driving agrarian change in the region have transformed the character of rural landscapes, livelihoods and social relations, dismantling well-established distinctions between agricultural/rural/traditional on the one hand and industrial/urban/modern on the other (Cramb et al. 2009). Diverse groups of smallholders have engaged the opportunities and constraints of agrarian change with greater or lesser degrees of success; some shift successfully from subsistence farming to a mix of market-oriented production, off-farm wage labour and service-sector activities; others experience dispossession and marginalization due to enclosures and labour exploitation (Macours and Swinnen 2002). Scholars have pointed out how the processes manifesting as agrarian change have 'peaked' due to global capitalist penetration, driving the shift from subsistence to intensified, commercial agriculture, dramatically affecting social relations in the region's frontier areas (Bryceson 1996;

Wolfram H. Dressler, Senior Lecturer, Anthropology, School of Social Science, University of Queensland, St Lucia, Queensland, Australia. E-mail: w.dressler@uq.edu.au; wolfram.dressler@mail.mcgill.ca; Michael Fabinyi, Postdoctoral Fellow, ARC Centre of Excellence for Coral Reef Studies, James Cook University, Queensland, Australia. E-mail: michael.fabinyi@jcu.edu.au; also Visiting Fellow, Resource-Management in Asia-Pacific Program, The Australian National University, ACT, Australia. 
Elson 1997; De Koninck 2000; Rigg 2005, 2006; Patel 2006; Zoomers 2010). In the end, some writers have even identified the 'end of the peasantry' and 'deagrarianization' as the defining features of the current transformation of rural livelihoods (Bryceson 1996; Elson 1997).

In this context, many studies have focused on how farmers adjust land-based livelihoods to the pressures, constraints and opportunities arising from agrarian change that penetrate upland frontier areas that, up until recently, were relatively difficult to access and outside of state control (Scott 1998; Baird and Shoemaker 2007). In describing these changes, however, an upland bias has emerged where researchers' field of vision focuses narrowly on the uplands as localities with distinct, coherent features (cf. Conelly 1992; Lacuna-Richman 2002; Dressler 2006; Cairns 2007; Novellino 2007), neglecting how families engage social relations to access opportunities in diverse social and environmental settings (see, in contrast, Berry 1993; Eder 1999; Tsing 1999, 2008; Zerner 2003). Consequently, the assumption often still holds - implicitly and explicitly - that agrarian change unfolds in a lock-step, linear fashion from subsistence to commercial agriculture (Raintree and Warner 1986; Rigg 2006; see also World Bank 2007; versus Hall 2009), missing how and why farmers negotiate agrarian change through multiple, diverse pathways, working social relations to access resources in areas well beyond 'the uplands' - from cities, the coastal zone and the sea (Zerner 2003; Eder 2005; Tsing 2008).

Recent work on agrarian change has elaborated on why extensive subsistence agriculture is declining in the Southeast Asian uplands, with changes in swidden agriculture receiving much attention (Padoch et al. 2007; Mertz et al. 2009). Experiencing population pressure, land shortages, declining yields and state coercion to settle, swidden farmers have adjusted older livelihoods, diversified, intensified production and/or abandoned fields altogether. ${ }^{1}$ In certain areas, however, agrarian change and swidden decline have tended to be irregular and recursive rather than fixed in place and linear in sequence. In the process of intensifying, swidden farmers engage opportunities that fall outside their traditional 'upland slot' that is so often reinforced in studies of agrarian change in Southeast Asia (cf. Eder 2006). While acknowledging the structural dimensions of agrarian change, in this paper, we offer greater insights into the socio-political nuance of agrarian change and swidden decline over time and space (see Batterbury 2001; Tsing 2008). In particular, we offer an ethnographic perspective of how swidden farmers' livelihood adjustments more often reflect diversified strategies that cross and bridge places through social relations, economic opportunities and changing environments. Emphasizing the social character of translocal connections, we describe how swidden farmers draw on social relations to negotiate the economic and environmental changes that arise from the agrarian transition in both terrestrial and marine areas. We elaborate on how various historical and contemporary pressures have merged: (1) leading indigenous peoples to respond to swidden decline by negotiating social relations to work new economic opportunities in multiple environments; and (2) that this manifests itself as a diversified, translocal landscape where people do different things in different places.

We focus on the Philippines - a country where state agencies have criminalized swidden as primitive, unproductive agriculture that threatens forests, requiring that farmers be resettled to adopt permanent agriculture, or engage in community approaches to stabilize fields (Dressler 2009). Those documenting this process reveal how development initiatives, land reform and intensification open former frontier areas to migrant settlers, capital, knowledge and markets

1 We consider the intensification of swidden practice as increas[ing] production from a constant area of land or obtain[ing] the same production from less land' (Brookfield 2007, 11). 
that redefine the role of swidden (Eder and Fernandez 1996; Eder 2006; Borras 2009). Experiencing the influence of globally driven change, including new commodities, ideas and values, swidden-based livelihoods have become increasingly translocal in character, influencing both state and local perceptions of the viability of swiddening (Appadurai 1996; Eder 2006; Dressler and Pulhin 2010). In the Philippines, these processes manifest as networks of social, political and economic organization that extend beyond the uplands, giving rise to individual and group interests in commodity production in both forest and marine environments (Tsing 2003, 27).

This is particularly evident on the frontier island of Palawan. Here, migrants have long been settling and searching for new commodities, encouraged by personal histories and the allure of emerging markets, to eventually co-mingle, learn from and compete with indigenous peoples already using lands for swidden (Eder 2004, 633). After successive inflows of migrant settlers into the uplands, the dissemination and adoption of new farming techniques and government pressure to settle and intensify, indigenous people's traditional mix of swidden agriculture and forest extraction has been in decline. Correspondingly, in the coastal areas of Palawan, livelihoods have become increasingly characterized by intensified efforts in marine harvesting and particular export commodity fisheries to which swidden farmers are now drawn. In particular, fisheries such as the trade in fresh ${ }^{2}$ and live groupers offer comparatively high returns to local fishers and now farmer-fishers (cf. Eder 2003), who, at the extractive end of this commodity chain, negotiate socio-political relations to feed the export grouper market in places as far as Hong Kong and Beijing. Strikingly, as many indigenous peoples have engaged this usually migrant-dominated grouper harvest, few have fully abandoned swidden agriculture.

We begin by examining how histories of agrarian change in the Philippines have come to pressure select indigenous Tagbanua - a 'swidden people' of Malay descent (Fox 1954) - to adjust swidden in response to declining yields, intensification and new, lucrative marine livelihood pursuits in Ulugan Bay, Palawan (Figure 1). Drawing on an extended case study, we consider how certain Tagbanua families ${ }^{3}$ have been prompted to step back from swidden agriculture due to declining yields and increasing debt, in order to harvest the lucrative grouper (e.g. the coral trout or leopard coral grouper, Plectropomus leopardus) on a near-permanent basis amongst migrant fishers and farmers. Building on Eder (2003), we show how several Tagbanua families cultivate swidden part time or temporarily abandon it as they move into marine harvesting and, in some cases, invest heavily in the grouper fishery. We examine in detail the reasons and means by which these Tagbanua farmers ${ }^{4}$ negotiated social relations, economic dynamics and environmental changes to enter into and often thrive in the grouper industry. We discuss how farmers' negotiation of social relations enables them to tap diverse and often lucrative livelihood strategies within and between places with which they are often not associated. We elaborate on how multi-sited household production draws on social relations to give rise to diverse, fluid and recursive practices such that, in the end, farmers and fishers cannot be considered as 'ideal types' with either an explicit marine or land-based livelihood (see Eder 2003) - further evidence for our conclusion that agrarian change is a dynamic, recursive process, contingent upon local and regional histories.

\footnotetext{
The term 'fresh' fish refers to dead fish.

These are 12 out of 60 households surveyed.

While both male and female household members negotiate this shift from swidden to mixed-species and grouper harvesting, we focus on the male household head's central role in negotiating and investing in both livelihood pursuits.
} 
Figure 1 The location of Ulugan Bay (Cartography ANU, 2009)

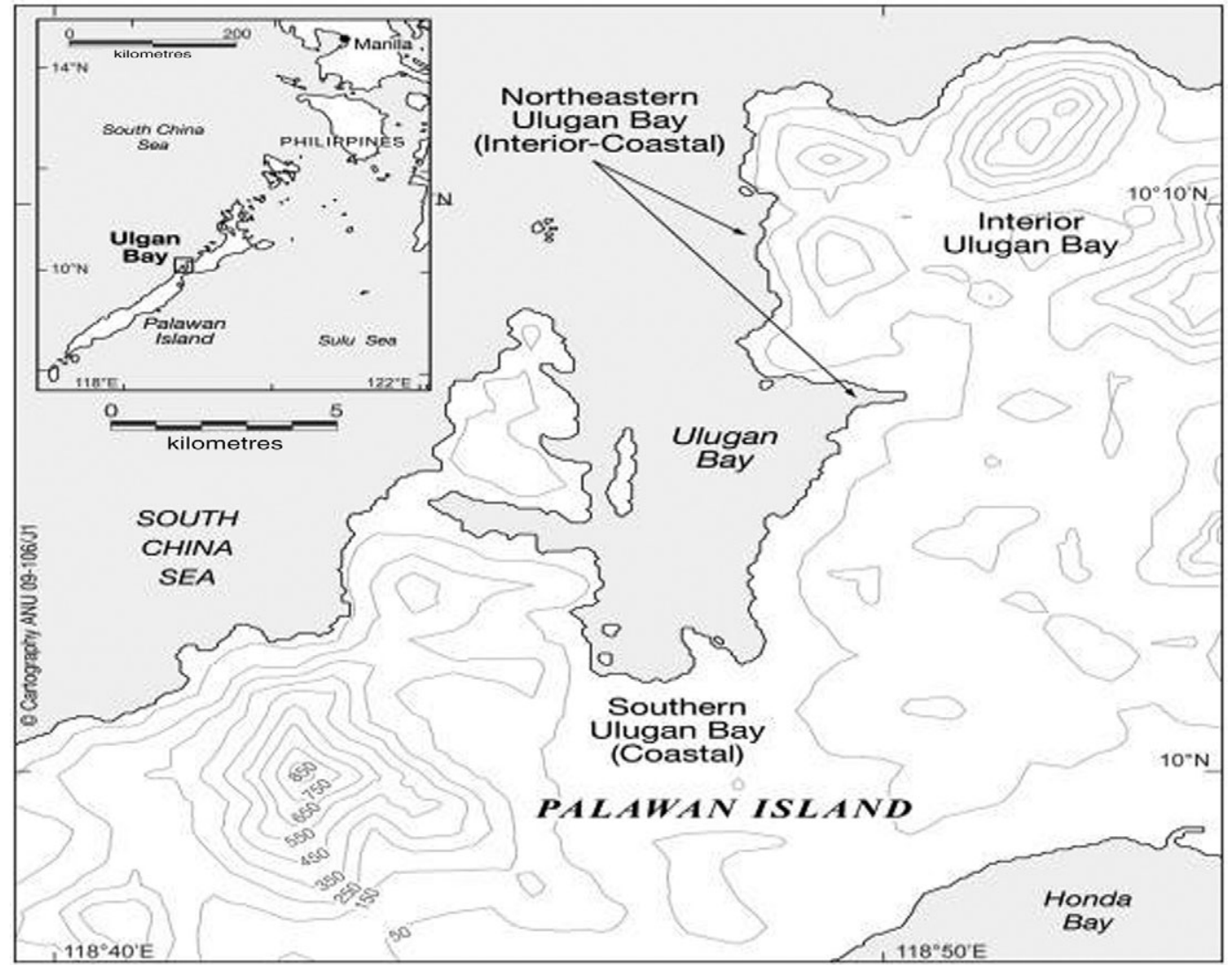

\section{METHODS}

The authors have conducted research in Palawan province since 2001 and 2005, respectively. Author 1 examined livelihood transitions in the south and interior areas of the Ulugan Bay region in 2001 and 2004, involving key informant interviews and a larger livelihood survey. From 2006 to 2009, he then conducted a purposive sample of 50 in-depth interviews on swidden change, 20 interviews focusing on the grouper harvest (Authors 1 and 2) and a livelihood questionnaire $(n=60)$ to help situate swidden and fishing in the broader livelihood context of the region. Questions elicited information on the social, cultural and economic importance of different livelihood activities among migrants and Tagbanua, and how these have changed over time independent of, and in relation to, social relations, markets and environmental change. ${ }^{5}$ Community leaders gave their free and prior informed consent for this research. We use pseudonyms for all people and places.

5 We focus on migrants and Tagbanua, but refer to the neighbouring Batak 'hunter-gatherer' people in certain instances, as none of these communities are indivisible. 


\section{AGRARIAN CHANGE IN THE PHILIPPINES}

Contemporary agrarian change in the Philippines has deep colonial roots. Under Spanish colonization (1521-1898), the state imposed the Regalian Doctrine, holding that all lands not registered as private title were held under the Crown as 'public domain' (Lynch 1982; Gatmaytan 1992). In time, the state recognized the leadership status of datus and chiefs (caciques) as having socio-political 'privileges' that enabled them to amass land holdings with tenant farmers on productive, relatively flat lands - the 'lowlands' (Borras 2007a). Various laws (e.g. the Spanish Mortgage Law 1893) enabled landed elites to register their holdings as 'records of possession' with the colonial government, formalizing claims over consolidated lands (Dressler 2009). The American regime (1898-1946) then drafted similar laws supporting the delineation of private title on usufruct holdings (e.g. the Torrens Land Titling System) (ibid.), ensuring that the aristocracy could expand its land holdings, increasing the levels of tenancies and landless poor (Borras 2007b). Set against the lowlands, people in the public domain occupied 'illegitimate' usufruct plots on less productive, undulating lands - the 'uplands' - subject to state enclosures such as timber concessions and national parks (Dressler 2009). American and Filipino foresters used these enclosures to help regulate swidden with a 'plant and punish' approach (Scott 1979).

After independence in 1946, the political economic structures that led to unequal land ownership, disenfranchisement and dispossession continued to characterize rural life in the Philippines (Kerkvliet 1974). Under Ferdinand Marcos from 1972 to 1986, for example, national land reform outcomes were far from optimal (Kerkvliet 1974; Borras 2007b). With capitalist penetration into rural frontiers, the consolidation of land for (non-traditional) commercial crops expanded, generating elite monopolies that further fuelled rural differentiation (ibid.). ${ }^{6}$ In many cases, tenant farmers devoted more time to producing for others' markets, losing greater control over land and resources due to existing policies and other practices that contained and criminalized extensive agriculture, particularly swidden farming. Securing control over 'kaingineros' [sic], the national government drafted laws, policies and programes reinforcing the need for swidden farmers to be identified, managed and/or resettled (Pulhin and Dressler 2009). In 1986, after Marcos' fall, swidden agriculture remained criminalized, under-capitalized and subject to landlords' usury practices (Borras 2007b); even with Constitutional reform ${ }^{7}$ and efforts to liberalize agriculture (ibid.), farmers could only cultivate swiddens on the proviso that they remained small and traditional, or were phased out through intensified, fixed-plot farming (Dressler 2009). From the late 1980s on, most agrarian reform programmes had achieved little success in restructuring and redistributing land holdings to the rural poor (Borras 2009, 69).

Yet as the Philippines is drawn into regional and global commodity flows, new opportunities open up for local people in what were once remote frontiers such as Palawan Island. Here, they engage in new livelihood pursuits in places that now fall outside the stereotypes of caste 'uplanders' and 'lowlanders' (Tsing 1993). Placed as they are, tenants, swidden farmers and forest dwellers will lack the secure tenure needed to gain the leverage to access the capital that influences control over production chains, often finding themselves negotiating the "extractive end' on unequal terms (swidden rice or NTFPs). In the face of weak rural markets, insecure

\footnotetext{
6 In this paper, differentiation refers to 'cumulative... process[es] of change in the ways in which groups in rural society... gain access to the products of their own or others' labour, based on their differential control over production resources...' (White 1989, 20).

7 Constitutional reform eventually supported new indigenous rights laws, ancestral domain claims (see IPRA 1997) and national parks legislation (see NIPAS 1992).
} 
tenure and declining swidden yields, such farmers increasingly opt for 'socially connected' diversification strategies in order to buffer vulnerability (Ellis 2000), reflecting what Turner (2007) calls 'selective diversification'. As a socio-political process, how such farmers diversify livelihoods depends on their ability to draw on and negotiate social relations that mediate and facilitate rights to access, and use a mixed portfolio of natural resources (Leach et al. 1999; Batterbury 2001; Ribot and Peluso 2003; de Haan and Zoomers 2005). As such, farmer livelihood decisions can be based in the social relations through which 'people move, acquire and exchange ideas and resources, and negotiate or contest the terms of production...' according to the specificities of place, connecting outward to people and resources of value in other places (Berry 1997, 1228). Should an opportunity arise, swidden farmers who experience reduced rice yields due to environmental decline, calamity and/or coercive policies will negotiate social networks to identify and enter into other lucrative pursuits across social and economic cleavages, and varied ecologies. Farmers will adjust their craft relative to their socio-economic position and extended social networks, with some retaining swidden and others relegating it as a 'side line' activity, or affirming they may 'continue again' soon (Dressler 2009). In rural areas, rather than contend that swidden and other extensive farming is in absolute decline due to commercial intensification, we see a patchy, irregular and recursive trend of farmers adopting more lucrative pursuits connected to the histories of places, social relations, economic dynamics and environmental change (Batterbury 2001; Tsing 2003). With the flow of capital and ideas moving within and between families, livelihood pathways are co-produced to 'socially bridge' the spaces between the so-called 'upland' and 'lowland' economies, breaking down the cultural spaces that 'uplanders' and 'lowlanders' supposedly hold.

\section{AGRARIAN CHANGE, SWIDDEN DECLINE AND GROUPER FISHING ON PALAWAN ISLAND}

Swidden-based livelihoods on Palawan Island have been subject to, but also rapidly moved beyond, the various labels (e.g. 'destructive', 'primitive', 'noble' and 'integral') so often used to characterize such upland agriculture in the Philippines (see Conklin 1957). The island's indigenous swidden farmers now negotiate the constraints and opportunities of agrarian change that were once considered peripheral to major political economic pathways. In particular, the Tagbanua of central Palawan (Apurhano), long considered 'swidden people' (Fox 1954; Warner 1979), have started negotiating a sustained anti-swidden policy, declining swidden yields and lower returns on non-timber forest products by intensifying farming practices and, increasingly, moving into new livelihood pursuits that fall outside of traditional upland categories. While Tagbanua populations near the Ulugan Bay area - this paper's case study region - have relied on swidden for subsistence, culture and worldview for centuries, and have traded with itinerant merchants for even longer (Kress 1977), today most have combined these activities with wage-based employment more integrated with capitalist markets (Venturello 1907; Conelly 1992; McDermott 2000; Dressler 2009). And, increasingly, in the process of co-mingling and competing with migrant farmers and fishers, many Tagbanua here have come to learn about, adopt and invest heavily in marine-based livelihoods with greater returns on investment. Recently, the so-called 'coastal peoples' and 'forest dwellers' in the area have overlapped in their pursuit of the export grouper fishery, which, driven by voracious Asian markets, has provided high prices for harvesters, buyers and sellers (Padilla et al. 2003). Below, we discuss Tagbanua swidden decline and involvement in grouper fishing.

Initially travelling north, the Tagbanua resettled in the then well-forested barangays in Ulugan Bay's northeastern interior and coast, as well as the southern and southeastern coast in the 


\section{Wolfram H. Dressler and Michael Fabinyi}

mid-to-late 1800s (see Figure 1) (Dressler 2009). These Tagbanua arrived in smaller, 'selfcontained' subgroups, first cultivating swidden on the flat, fertile valley lands flanking Ulugan and St Paul Bay (Fox 1954; Marche 1970 [1890]). Many travelled to parts of Ulugan Bay to work in logging operations or settled due to marriage and custom (Dressler 2006).

From the 1950s until the present day, concurrent to Tagbanua occupancy, migrants departed in waves from Luzon and Mindanao to settle in the interior valley along the northeastern coast of Ulugan Bay (see Figure 1) (Kerkvliet 1977; Chaiken 1994). Migrant farmers settling in the 1950s and 1960s recount how unequal tenant-landlord relations, their inability to secure land holdings and socio-political conflicts prompted them to relocate on Palawan (see Eder and Fernandez 1996). Upon settling, they held subsistence livelihoods similar to those of the Tagbanua, clearing forests for swidden, harvesting rattan and supplementing their diet with fish caught using dugout canoes. As migrants and Tagbanua co-mingled, the local population was relatively small and homogenous and oriented towards reciprocal labour relations for livelihood support. The area was land rich and people poor.

While not a distinct historical moment, rural differentiation arose progressively, such that 'social rank' was increasingly articulated through control over private holdings, farm wealth through surplus extraction, ethnicity and settlement location (cf. Akram-Lodhi and Kay 2010a). Migrants settling in the area hired Tagbanua labour to help clear forests for swidden and paddy farming on flat, fertile alluvial land. The more time Tagbanua spent labouring for migrants and emerging markets, the less time they invested in familial production, particularly swidden (cf. Eder 1987). As migrants secured control over most productive resources, they claimed flat lands through seizures or purchases, converted swiddens into paddy fields, increasingly tendered lands as private title, and built up paddy farming and cash cropping (Dressler 2006). Many Tagbanua found themselves dispossessed, working as tenant sharecroppers, and cultivating swidden in the bay's interior forest areas. Without access to private title and productive assets, they had little chance of 'improving' their livelihoods through intensification. Meanwhile, as we will show, those wealthier migrants and Tagbanua who were now experiencing declining rice yields and could access coastal areas either took paddy profits to buy, or have someone build, a boat to begin mixed-species fishing in Ulugan Bay.

The southern and southeastern coastal areas flanking the interior valleys of the Bay hosted a mixed group of migrant farmers and fishers who co-mingled with those Tagbanua already present, as well as those from the interior valley areas (see Figure 2). Those migrants specializing in fishing and paddy farming settled amongst the Tagbanua and other migrants who had worked for the initial logging operations. In the late 1940s, several Visayan ${ }^{8}$ families settled in the south of the Bay, securing claims to private land (Rivera-Guieb 1999). Along the southeastern coast and interior, settlement patterns were characterized by core settlers clearing and claiming lands near the coast, and then supporting the arrival of next of kin a few years later on peripheral lands. While Cebuano ${ }^{9}$ fishers settled the western coast of the Bay, most Visayans were busy mechanizing, intensifying and expanding their paddy rice farms on the private lands they had claimed from the commons. With paddy profits in hand, secure bank loans and other sources of income, these households soon intensified their fishing activities, buying larger boats with bigger engines and more crew. Despite some Tagbanua farming paddy and fishing, most remained tenant sharecroppers and/or relied on swidden for family food crop production, albeit now with declining yields.

\footnotetext{
The Visayas are a group of islands in the central Philippines.

Cebu is an island in the Visayas.
} 
Figure 2 Tagbanua movement (select households) (Cartography ANU, 2009)

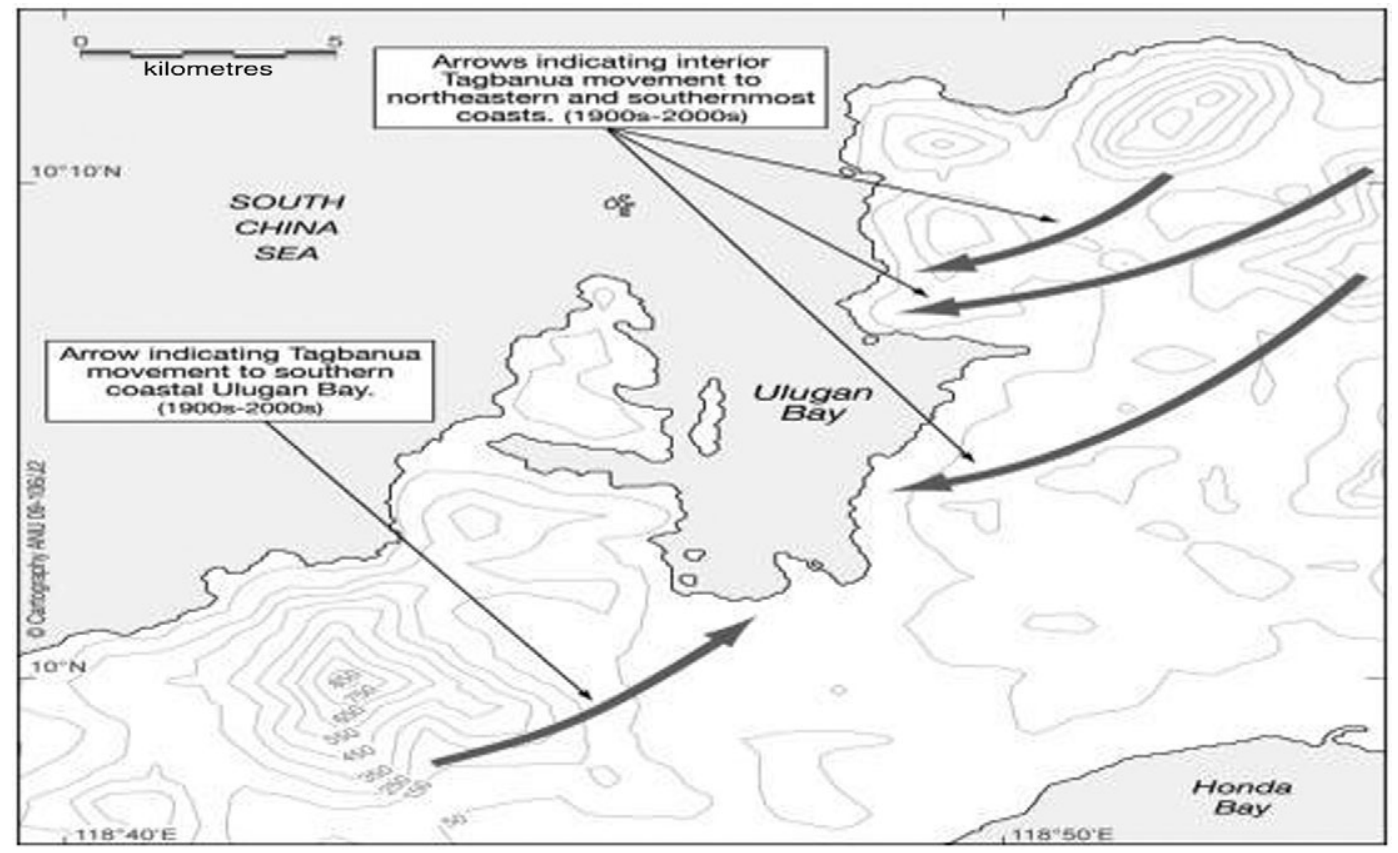

By 2001, in the northeastern interior region, an earlier livelihood questionnaire $(n=157)$ indicates that the area's once relatively homogenous population in the 1970s had diversified into no less than 13 different migrant ethnicities, outnumbering the Tagbanua. As migrant and wealthier Tagbanua began diversifying their livelihoods (e.g. carpentry, sari-sari (general) stores and off-farm labour), most Tagbanua households in the forest still relied on swidden and NTFP harvesting, but with lower returns on investments in farming and off-farm labour (ploughing migrants' fields etc.). In this area, Tagbanua farmers have seen a gradual decline in the overall size and yields of swiddens. Ascertaining household field size with a measuring tape and asking farmers to estimate rice yield based on seed input (per ganta/hectare ${ }^{10}$ ) and annual return per hectare (gross average), we see a decline in field size and overall rice yield. For example, in one forest sitio, swidden yields $(n=22)$ went from a maximum of 650 kilos per hectare $\left(\mathrm{kg} \mathrm{ha}^{-1}\right)$ in the $1980 \mathrm{~s}$ to a low of $115 \mathrm{~kg} \mathrm{ha}^{-1}$ in 2008. Other scholars give similar estimates in 2000 for Tagbanua and Batak, averaging between 615 and $400 \mathrm{~kg} \mathrm{ha}^{-1}$ annually, respectively (McDermott 2000; Novellino 2007).

Just like their parents, most fifth-generation Tagbanua remained in the area because of fewer opportunities to move beyond swidden and forest extraction (rattan, almaciga resin, honey etc.). Recently formed Tagbanua households of this generation stayed put due to degrees of 'dependency' on the forest and the land, with many young to middle-aged Tagbanua relying on a dwindling supply of forest products and swidden rice (due to decreasing soil fertility, pests and weather affecting overall yields). Most Tagbanua interviewed were dissatisfied with current rice yields under shorter 3-4 year fallows (historically, fallow periods were 10-15 years).

10 One ganta is $2.24 \mathrm{~kg}$ of threshed/milled rice; one cavan/sacko is $56 \mathrm{~kg}$ of milled rice. 


\section{Wolfram H. Dressler and Michael Fabinyi}

Migrant pioneer settlers and their offspring (20 households, 18 per cent of questionnaire respondents), born in the early 1970s, stated they remained to access a 'better livelihood' (15 households, 14 per cent) and 'get married' (13 households, 12 per cent). Compared to the Tagbanua, many first-generation migrants born in interior sitios were raising children and cultivating irrigated paddy rice on cleared lands inherited from their parents. Thus, firstgeneration households were easily incorporated into the paddy rice economy that their parents had set up through social and political ties controlling land and capital, as well as Tagbanua labour for paddy field expansion, and/or engaging the diverse opportunities in off-farm employment for which they qualified. As a result, several generations of migrants have secured control over property, agricultural outcomes and political authority in their localities (AkramLodhi and Kay 2010b).

A similar process has unfolded in the southeastern reaches of Ulugan Bay. Here, Tagbanua and poorer migrants lament the fact that their swidden yields are declining and note that paddy farming is their most productive option. However, as elsewhere, because wealthier migrants own most of the flat, productive titled land for paddy rice, poorer Tagbanua in the area have been unable to secure the productive assets with which to begin their own paddy plots, opting instead to farm swidden and/or sharecrop as tenants on the lands of wealthier landlords, as the migrants once did at their place of origin.

Yet, as with many farmers experiencing declining swidden harvests, most now turn to new and/or existing social networks to enhance their potential to access and use capital and resources for different livelihood pursuits. In all of the interior and coastal areas, while not 'letting go' of swidden farming for food security, more and more Tagbanua swidden farmers (12 of 60 surveyed) are negotiating shifting social relations and knowledge to draw on small profits - whether by being farm-hands or crew on migrant fishing boats - and family labour to help scale up fishing activities, particularly for the lucrative grouper trade.

\section{Farmer Gone Fish'n? The Rise of Grouper Fishing}

While Visayan people in Ulugan Bay have for generations caught grouper as part of more capitalized multi-species commercial harvests, and the Tagbanua have long used various fishing techniques for subsistence, it has only been relatively recently that fishing for grouper has attained greater value as part of the lucrative live fish trade and the fresh grouper fishery (for detailed analyses of these respective fisheries in Palawan, see Padilla et al. 2003; Fabinyi 2009). ${ }^{11}$ Both migrants and, to a lesser extent, Tagbanua began moving into the live fish trade more intensively in Ulugan Bay from the early 2000s, with the latter facing various factors affecting their level of engagement and success.

As migrants began fishing more intensively for fresh and live grouper in the mid-2000s, Tagbanua farmers who were frequenting the coast to trade and fish intermittently soon followed suit. They did so because the risks of entering the grouper harvest are perceived to outweigh the benefits of remaining with swidden fields with poor soils, pests, declining yields and increasing regulation. With markets for the live fish trade expanding throughout Palawan in response to continually strong demand in East Asia, the general draw of Tagbanua farmers towards mixed-species harvests became increasingly focused on catching the prized grouper. In time, many Tagbanua would learn from migrants about the harvesting techniques and capital

11 Historically, Tagbanua men and women engaged in spear fishing from the shore, hook-and-line fishing, net-fishing from paddle dugout canoes, bark-based poisons, fish corrals with bamboo as well as fish traps and rods. In contrast, Visayans have historically drawn on more highly specialized and capitalized harvesting techniques (Seki 2004; Fabinyi 2009). 
Figure 3 Fishing grounds (Cartography ANU, 2009)

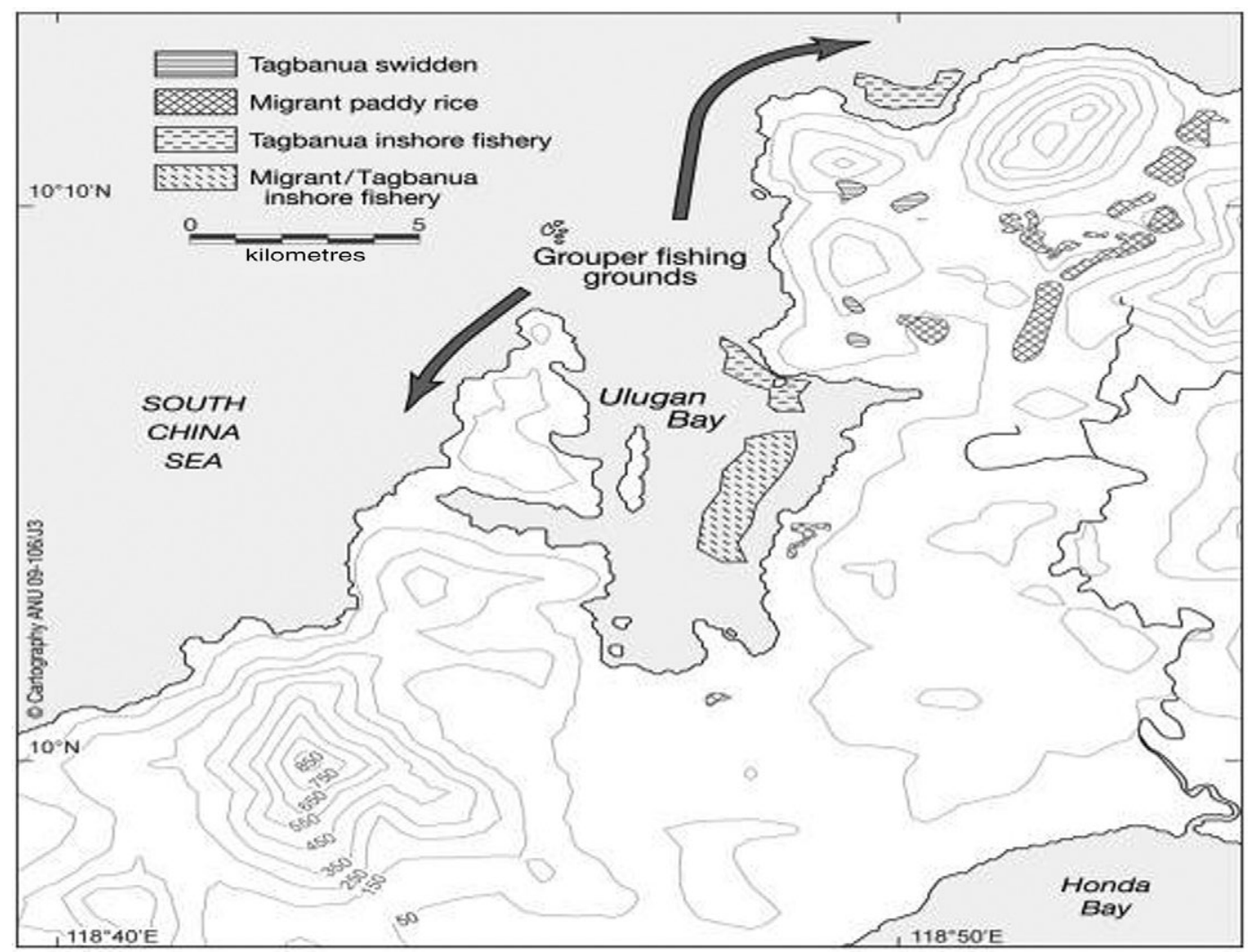

necessary for harvesting grouper. However, poorer Tagbanua were restricted in investing in the harvest for both financial and socio-political reasons. In the first case, while less difficult for long-term migrant fishers and paddy farmers who could sell their surplus to secure sufficient finances, Tagbanua swiddeners with little, if any, income from the sale of surplus rice have had difficulty overcoming the high start-up costs of fishing capital - between P15,000 (\$300) and P50,000 (\$1,000) or more for medium- to larger-sized boats with engines between 8 and $24 \mathrm{hp} .{ }^{12}$ Most of these boats, ranging from 5 to 10 metres in length, are necessary to access the better fishing grounds for grouper that lie outside of Ulugan Bay (see Figure 3), in part due to the overfishing of grouper within the Bay (Rivera-Guieb 1999). At the outset, such costs are relatively unattainable for most Tagbanua swidden farmers, requiring that they first work as crew for medium- and larger-scale fishing boats owned by (usually) Visayan migrants. The highly specialized skills required for live grouper fishing (e.g. deflating the swim bladder of the fish once it has been caught and nursing it live until reaching the shore) also require knowledge

12 Similarly, most swiddeners do not have private title to use as collateral to secure loans from banks to put towards building or buying the larger boat and engine necessary for grouper harvesting. 
transfer from more experienced migrant fishers (see footnote for more details). ${ }^{13}$ Many Tagbanua began working on migrant fishing boats and acquiring their fishing knowledge after living in the area for some time.

The ability of Tagbanua to work on migrant boats is not, however, a straightforward process. Social relations between different ethnic groups in the Philippines and in Palawan are sometimes fraught (Eder 2004), particularly as farm and off-farm wealth dictates power and authority along ethnic lines. Tagbanua must negotiate the ethnic cleavages of social relations by way of social acquaintance, intermarriage, farm labour relations and, pragmatically, by forming working relationships on fishing boats. Tapping and investing in social networks to bypass ethnic barriers opens up access, use and investment opportunities in the grouper fishery that is often defined by the control and authority of financiers and boat owners with secure holdings over property, productive assets and surplus - whether in paddy rice and or fishing. In particular, when Tagbanua opt to work as crew, they must often negotiate a complex of power structures through generating relations of acquaintance and trust when financiers and boat owners choose crews: boat owners have to be sure that fishers will return to sell their fish to them. As mixed Tagbanua-Cuyonen boat owner Elizalde Maldero stated, 'it's always better to get those whom I really trust' (San Nicolas, 20 July 2009). Similarly, boat owner Dinah Balcosa (a migrant originally from Romblon) pointed out that 'I only hire relatives ... they are my nephews' (Brgy Manay, 7 November 2009). Kin networks will usually be favoured in these circumstances where trust and a personal connection have already been established, but when boats are short of crew members, they will often take on fishers without much experience. In time, among crew members, the shared experience of working at sea tends to form close relations of trust (cf. Russell 1997, 85-6; Fabinyi 2009, 88). As fish trader Ricardo de Leon described, Tagbanua who moved into fishing would originally work amongst themselves and not with migrant fishers, and were noted for their lack of skill with grouper fishing techniques, but as they went out more often they became just as skilled: '. . now they can understand each other and they have good relationships... Sometimes, in one boat, aside from Cebuanos, there are also Cuyonons and Tagbanuas aboard...' (San Nicolas, 7 November 2009). In this respect, developing trust between Tagbanua and migrants does take time, requiring that they become familiar with one another, each other's families and even each other's idiosyncrasies. The trust and confidence that develops in believing others will do the 'right thing' helps Tagbanua negotiate the political barriers between themselves, wealthier migrants and their fishing practice (e.g. people, knowledge, assets and surplus harvests) (Granovetter 2005, 33).

Through everyday activities and livelihood transactions, the experiences of several Tagbanua, particularly Hilarion Rodriquez, illustrate how they have adjusted their swidden-based livelihoods as they enter into fishing amongst migrants. Descended from a locally respected and powerful lineage within the Tagbanua community, with kin links to Aborlan and Napsa'an, Hilarion's family settled in the interior regions of Ulugan Bay in the 1900s (Dressler 2009). Hilarion, his parents and grandparents collected non-timber forest products (NTFPs), cultivated swidden for subsistence and tended the fields of migrants for cash for several decades. It was not

13 Depending on their preference for and proficiency with different techniques, Tagbanua fishers typically use one or more of several variations on the hook-and-line method to target grouper. These include hooks baited with smaller fish such as scads, or hooks with lures made from rubber, shiny fibres, shells or chicken feathers. Although fishers use these methods to target grouper specifically, the majority of any fish catch is usually made up of a mixed-species bycatch of various reef fish. When live grouper are caught, fishers will work hard to keep them alive by easing their transition out of deep water: the fish is brought up slowly and after it is caught; it is then lowered underwater again for a short period of time inside a small cylindrical cage. After this gradual 'decompression', the fish are placed inside a small section of the hull, which has been designed to have water flowing through it as a natural aquarium. 
until the mid-1990s that Hilarion and his siblings moved to the coast of Ulugan Bay, having difficulty getting by on the low overall returns from NTFP harvesting and swiddening. When asked why he transferred he stated (San Nicolas, 7 November 2009) that: 'Because it is here where my line of interest for a living in fishing is near; the source of living there [in the interior] is rattan and kaingin . . but it is still not enough work for my family.'

After living on the coast for a while, Hilarion became acquainted with migrants through everyday neighbourly relations and work transactions. In time, he was hired as a carpenter to build migrant boats on demand and, proving to be a reliable and responsible worker, soon joined in the fishing trips with other migrants. Hilarion worked both carpentry and fishing in such a way that one activity supported the other.

Hilarion first learned how to build fishing boats by working as an apprentice with migrant boat makers; receiving cash for his labour, he then purchased carpentry tools for boat building. He experimented by making his first dugout canoe from local timber that he and his brothers hauled out by water buffalo from the forest interior. Reaching the coast, he then processed the timber for the hull of his first motor-driven outrigger canoe. Now known locally as an expert boat maker, he has already built four medium- to large-sized boats for migrants, netting him an annual total of P60,000 (\$1,200) (at about P15,000 (\$300) per boat), a sizeable income when compared to swidden harvesting. In turn, he has used these funds to support his family's fishing enterprise, with his siblings now also owning and operating motorized fishing boats. Contrasting his livelihood with his father's swiddening, he speaks enthusiastically about plans to expand his fishing enterprise because, as he says, 'It's quicker to get money in fishing' (San Nicolas, 7 November 2009). In this sense, Hilarion and his brothers' fishing livelihoods are part of a broader kin-based, extended household enterprise, with strategies linked to different environments.

With this shift to fishing, he no longer actively engages in swidden, but still has several plots in fallow further into the forested interior. He and his wife will harvest different root crops and fruits from trees they had planted in these fields while still living in forest villages. Moreover, the fact that his other siblings and cousins still have swiddens, though now also cultivated infrequently, enables him to plant and harvest upland rice and cassava in their fields. While they rely on others to tend these crops, Hilarion and his family have access to rice and cassava (Manihot esculenta) as starchy staples to keep family consumption costs down, freeing up money for investments in fishing and other pursuits (Dressler and Pulhin 2010).

More generally, one finds that Tagbanua fishing trips from Ulugan Bay are usually conducted with three or four people on a medium-sized boat. Lasting between three to four days, these trips will sometimes take fishers tens of kilometres away from Puerto Princesa in search of the best fishing grounds. Although the Tagbanua catch is almost always made up of a mixed-species catch of reef fish (see Table 1), they make explicit reference to also focus on the coral trout ( $P$. leopardus). ${ }^{14}$ In the fishery, the lines between the fresh and live grouper harvests are blurred, as generally crews will use the same vessel and gear to catch both. While most will aim to target live grouper, the high mortality rate means that the fish are often sold fresh instead.

The above Tagbanua swiddeners have clear economic motives to engage with grouper fishing. Most fishers in the live fish trade typically describe the catch of a good-sized, live grouper as a 'jackpot': at a price that often increases to more than P2,000 per kilogram, this fish is simply much more highly valued than any other fish or commodity in the area - inside or outside the forest. Tagbanua farmers who have invested in fishing often described the benefits

14 While different nearshore species are caught throughout the year, the peak time for fishing grouper is during the Southwest monsoon of habagat (late May to September). Outside of habagat, Tagbanua will either continue fishing for grouper but with lower returns or work other gear such as net-fishing, and they often maintain their swiddens during this period. 
Table 1. Fishing catch and profit ranges

\begin{tabular}{llrr}
\hline Targeted fish & $\begin{array}{c}\text { Approximate price range } \\
\text { per kilogram }\end{array}$ & $\begin{array}{c}\text { Reported catch } \\
\text { range }\end{array}$ & $\begin{array}{c}\text { Potential gross } \\
\text { return }\end{array}$ \\
\hline Isdang bato (assorted reef fish) & P15-100 & $20-80 \mathrm{~kg}$ & $\mathrm{Up}$ to P8,000 \\
Fresh P. leopardus, $500 \mathrm{~g}$ to $1 \mathrm{~kg}$ & $\begin{array}{c}\mathrm{P} 400 \text { (Ulugan Bay) }-650 \\
\text { (Puerto Princesa City) }\end{array}$ & $2-15 \mathrm{~kg}$ & $\mathrm{Up}$ to P9,750 \\
Live P. leopardus, $500 \mathrm{~g}$ to $1 \mathrm{~kg}$ & $\mathrm{P} 1,400-2,000+$ & $1-9$ pieces & Up to P18,000 \\
\hline
\end{tabular}

The catch ranges are estimates reported by respondents from interviews.

of fishing as related to the relatively immediate nature of the profits: "They are fishing now because it's quicker to make profits in fishing' was a version of a common explanation among those who had begun to invest in fishing. Indeed, while most of the fish catch is of lower-valued assorted reef fish, catching a single 'good-sized' (500 g to $1 \mathrm{~kg}$ ) live coral trout can often bring a harvester more than P2,000 (US $\$ 40)^{15}$ (see Table 1).

There are many, almost exclusively migrant, buyers of fresh fish based around Ulugan Bay. Tagbanua either sell their fresh fish to these buyers or travel directly into Puerto Princesa City to obtain a higher price. From the City, the assorted reef fish are usually sold locally at the market. Tagbanua who have recently entered the grouper trade sell their fresh and live catch to buyers who export the grouper across translocal commodity chains, from Manila to various Asian destinations, mostly via Hong Kong. ${ }^{16}$ The exchange partnerships that many Tagbanua enter into with buyers (suki) - usually according to patron-client type relations help finance their new enterprise (up to P6,000 (US \$120) per trip). For the few Tagbanua who own their own boat or who are reasonably well-off, they can fund each trip upfront independently. Other less prosperous Tagbanua (and migrant) farmers, however, are obliged to get assistance from a financier. The financier will fund the trip on the understanding that the Tagbanua will sell all of their fish to him on their return. There is no interest on such loans; instead, the Tagbanua fishers will pay back the loan when they can, and are bound to sell all of their fish to the financier. Although Tagbanua and other fishers are not necessarily bound to sell at a lower rate, they do not have the ability to choose higher prices that may be offered elsewhere.

More generally, as fishers involved in the lucrative grouper fisheries have been able to access economic benefits, their ability to maximize these benefits and move further up the commodity chain faces several structural constraints. While getting work as a crew member may not necessarily require overcoming too many direct economic constraints, the ability to own and operate a boat usually involves either going into debt with financiers or through long-term savings (Fabinyi 2009), a position exacerbated amongst many swiddeners with limited capital and savings. The general position of many Tagbanua fishers in the trade is constrained by a lack

\footnotetext{
15 Because grouper are caught one by one over wide fishing grounds, and then need to be kept alive for the duration of the trip, fishing for live grouper is considered to be a higher-risk fishery, but one where the potential rewards are much greater than in many other fisheries in Palawan because of the price.

16 Migrant and Tagbanua fishers are not able to sell live grouper within Ulugan Bay, as the harvesting of live fish in Puerto Princesa City - the administrative region of which Ulugan Bay is a part - is banned. They sell instead to buyers based at the southern edges of the neighbouring municipality of San Vicente. From San Vicente, the live fish are also flown out for export. High-quality fresh grouper are sold instead to buyers in Ulugan Bay or in Puerto Princesa City, who also go on to export the fish.
} 
of alternatives for credit and financing, access to information and the ways in which actors at the 'top' of the commodity chain are able to more successfully organize themselves to control profits and capital investments (Russell 1987; Padilla et al. 2003).

The above transactions show how Tagbanua sit at the extractive end of grouper commodity chains, with fairly limited political and economic leverage. Consequently, many Tagbanua have adopted fishing in the context of broader livelihood strategies that help them buffer risk and uncertainty. As Eder has argued with reference to coastal communities elsewhere in Palawan, 'fishing itself, as a livelihood option, is always located on a field of other livelihood options' (2003, 215). Those Tagbanua we interviewed frequently stressed that although they are keen to engage with fishing-based livelihoods, this does not necessarily mean that they will totally abandon farming pursuits. Instead of being viewed as a replacement livelihood, fishing is often seen as complementary to farming. For example, a Tagbanua, Restofar Castro, explained that when the weather for fishing was too rough, he would attend to his swidden (kaingin) plot: 'In fishing when the seas are rough I seldom go out... I'm here with my kaingin' (San Nicolas, 12 December 2006). In addition, many fishers who harvest grouper will only fish seasonally; farming during one season and fishing the next. Restofar, for example, joins a grouper fishing crew for much of the year but during the rainy season works on a paddy farm and swidden. In time, the relationship between earnings from farming and fishing is mutually supportive. Tagbanua who have made profits from fishing will, for example, frequently invest them in their farm: 'If you have earnings from fishing, you can use it to pay for labour so it will be easier for you to work in the farm' (Sitio Tangag, 15 December 2006), said Pedro Daganta, a Tagbanua who maintains a rice farm but also fishes grouper. For Restofar, the money earned from grouper fishing is explicitly used to enhance his farming. Like Pedro, he invests his money obtained from fishing into labour for the paddy farm he works on, owned by his brother-inlaw. Similarly, having invested in fishing, many Tagbanua have avoided abandoning swidden or other farming completely. Restofar Castro, for example, hopes in the future to invest further earnings from fishing into a water buffalo. He views fishing as a means to enhance his farming, as opposed to a permanent, full-time new livelihood. When asked to choose his preference between fishing and farming in the future, for example, Juan Martinez stated: 'I won't choose because they're both my work...' (San Nicolas, 16 December 2006).

In this sense, while swiddeners are moving steadily into fishing, particularly the grouper fishery, people still draw on a range of social relations and livelihood activities that they know best across both coastal and interior areas, particularly those supporting subsistence. The ways in which social relations are drawn on as they extend across such places creates a landscape mosaic of coastal occupation and use, spaces of intensive paddy production, extensive swidden clearings, and fallow regrowth in swidden spaces over time (see Figure 3). In the cases described, cleared and fallowed swidden are maintained by extended kin and family, while others try their luck with paddy rice; still others skip the land-based intensification route, opting to invest in mixed-species fishing and lucrative grouper harvesting. From this perspective, rural livelihood changes are thus best understood across a range of local contexts, demonstrating the recursive non-linearity of agrarian change.

However, although the price of live and fresh grouper has risen in recent years and markets have expanded, attracting swidden farmers to grouper fishing, important factors impact negatively on the future economic viability of the practice. High levels of overfishing and the use of sodium cyanide in the live fish trade has resulted in considerable habitat destruction and grouper stock decline in some waters around Palawan (Padilla et al. 2003), leading the provincial government to attempt to introduce a fixed quota system that would drastically reduce the amount of fish allowed to be exported from the province. The ability of grouper fishing to 
provide Tagbanua with a lucrative long-term opportunity amidst declining swidden yields is thus considerably constrained. Indeed, both Tagbanua and migrants describe how fish stocks in Ulugan Bay have declined rapidly in recent years, forcing them to travel further for more plentiful fishing grounds (see Figure 3).

\section{DISCUSSION AND CONCLUSION}

The notion of indigenous swidden farmers being confined to upland areas as they negotiate their livelihoods to the challenges and opportunities of agrarian change is less absolute than the literature often suggests (see Lacuna-Richman 2002; Dressler 2006; Novellino 2007). Rather than see the progressive phasing out of swidden-based livelihoods along a linear trajectory confined to upland people and places (see Warner 1979; Raintree and Warner 1986; Rigg 2006) due to the 'acceleration' of agrarian change, we see farmers often associated with being in 'the uplands' creatively engaging constraints and opportunities in diverse social and environmental spaces - spaces with which they are apparently not associated (McKay 2005a,b). Eder (1999, $2003,2006,2008$ ) notes that as households engage certain aspects of agrarian change (lucrative crops, new markets, wage labour etc.), they diversify and/or intensify their existing livelihood strategies, or draw on new activities further afield in order to make ends meet in, and according to, changing situational contexts. Yet, the processes by which swidden farmers access these new opportunities in relatively unfamiliar environments is far from straightforward and is constantly changing. Engaging successfully with a new enterprise requires that so-called indigenous uplanders effectively deal with ethnic and social relationships that are often structured along lines of power and authority rooted in the control and accumulation of (farm and off-farm) capital, surplus extraction and wealth over time and space; in many ways, these social relations further span unfamiliar places and often serve as barriers rather than openings to new opportunities (cf. Berry 1989; Sikor and Lund 2009). The ways in which farmers become familiar with and negotiate ethnic ties and social relations in rapidly changing landscapes thus affect their ability to secure opportunities from people and situations that are often difficult to access.

Crucial, then, is the need to understand how and why farmers draw on and access social relations across a range of spaces to respond to social, economic and environmental change arising from localized agrarian change. In this paper, we have shown how Tagbanua farmers negotiate social relations to respond to swidden decline and new fishing opportunities within and between interior and coastal areas, and how this reflects a translocal, landscape mosaic. We have emphasized, in particular, that the ways in which Tagbanua households - swiddeners with limited landed capital and political leverage - diversify and specialize in different areas are accomplished by negotiating both past and present social relations that enable them to access, and become familiar with, new economic opportunities in marine environments. The success of grouper fishing as a new livelihood strategy has largely depended upon the ability of capital poor Tagbanua farmers to engage with migrant fishers, borrow capital and, of course, learn new skills particular to the craft and environment - these skills are complex, requiring the accessing, manufacture and specialized use of fishing gear and techniques often considered separate from uplander lifeways. The Tagbanua who have moved to the coast and successfully entered into live grouper and mixed-species harvests on a sustained basis have negotiated important social relations and ethnic ties to access economic networks for resources and capital assets (financial, physical and human etc.) that otherwise might not have been available. Once they move deeper into these grouper fisheries, however, their ability to maximize benefits faces mounting political and economic constraints. Power and authority tend to become more pronounced further up 
the grouper commodity chain, as reflected in and defined by 'upper-level' financiers, buyers and wealthier fishers drawing on both land and non-land capital as leverage.

Partly because of these structural constraints, including those Tagbanua who have focused more on live grouper and mixed-species harvests, most diversify their livelihoods by drawing on social relations and resource portfolios that span the 'uplands' and 'lowlands'. As social and economic relations span spaces to give rise to socially connected livelihoods, one begins to see the interrelatedness of diverse fishing and farming practices (Eder 2003, 2008) criss-crossing, manifesting in coastal and interior areas. While often not always apparent, rural households in coastal areas combine and draw on both land- and marine-based harvesting in an interrelated manner (Eder 2003). In some cases, as shown, even those who have found fishing an attractive option tend not to completely abandon swidden for a more financially rewarding activity. In cases where Tagbanua farmers have difficulty intensifying production on the sea or land due to high start-up costs, few assets and ethnic barriers structured by capital and wealth accumulation, many have indicated during interviews that swidden remained a crucial, low-cost way to support sustenance and income through family food crop production. As elsewhere, the availability of staple root crops (e.g. cassava) is critically important when rice stocks have already been consumed prior to the year's main harvest, and when heavy rains make fishing with a paddle dugout canoe difficult (see Dressler and Pulhin 2010). In contrast, most Tagbanua swidden farmers at Ulugan Bay are keen to move into fishing, with some moving to the coast to fish on a regular basis - becoming, in effect, near full-time fishers by negotiating access to start-up capital, particularly that of medium to lower cost. Remarkably, even then those farmers who have 'gone fish'n' draw on social networks to ensure that their family or next of kin tends to their swiddens in interior forest areas. In the process, an interior swidden landscape in various stages of fallow regrowth is used in place as other livelihood activities are pursued in the coastal zone within and through social relations and connections - with the availability of resources in each place defining the viability of multi-sited diversification.

Given this evidence, we find that the broader binaries of 'upland' and 'lowland' livelihood begin to break down as the various social and economic connections across livelihoods and environments bridge places. The case of the Tagbanua swidden farmer and grouper fisher illustrates this well. While the evidence points towards a general decline in swidden agriculture as 'upland' farmers opt for more intensified commercial agriculture (paddy rice) and off-farm labour opportunities, many have worked social relations with their migrant neighbours, their own family and kin, and other Tagbanua to move into lucrative marine harvesting, but not uniformly so or at the expense of land-based practices. Rather than abandon swidden wholesale, many Tagbanua farmers have found creative and diverse ways to negotiate access opportunities that have enabled them to maintain diversified livelihood portfolios from the land and sea.

The short- and long-term outcomes of agrarian change depend upon how and why individuals and families draw on particular social relations to engage economic constraints and opportunities, as well as environmental changes. In many respects, examining how farmers negotiate agrarian change according to local contexts and social relations steers us away from interpreting the outcomes of agrarian change in terms of the binary relationship between the uplands and lowlands. Multi-sited, long-term, local ethnographic analysis forces us instead to consider how agrarian change and swidden 'decline' is a 'spatiotemporally differentiated process' embedded within and articulated through local socio-politics, economy and environment (Castree 2008, 156; Tsing 2008). As Tsing (2008) argues, the values, meanings and understandings of commodities are contingent upon, and mutually constituted through, multiple 'historical assemblages, made from national and [local] ethnic encounters, and their ability to form links 


\section{Wolfram H. Dressler and Michael Fabinyi}

with global circuits' (41). Rather than adhering to the linear pathways of economic logic, as some conceptions of agrarian change follow, commodity co-production is incremental, negotiated, learned and acted on, unfolding progressively and recursively according to how social, economic and environmental factors affect the circumstances of local people in various places. Scholars now suggest that we focus less on the intelligible structural 'linkages' that 'line up places and people in an assembly line' waiting to harvest and fuel commodity chains (Eder 2003; Zerner 2003; Tsing 2008, 48) and instead on how social relations work as 'social glue' that bridges different peoples' livelihoods across areas. In the Ulugan Bay area, we have seen that certain socio-political, economic and environmental pressures have caused many Tagbanua farmers to partially rethink swidden and forest-based livelihoods according to their past, present and future circumstances. Yet how Tagbanua deal with growing commodity relations and the need to intensify on land and in the sea is contingent upon how they engage local histories, social relations and ethnic ties to negotiate changing economic and ecological characteristics. As a result, the outcomes of agrarian transitions reflect less of a transitory pathway than a recursive and dynamic process unfolding within, between and upon places in both coastal and interior areas. The recursive nature of such agrarian change thus becomes manifest as a socio-ecological landscape mosaic that arises through the social relations and connections of varied livelihood strategies across the coastal and interior areas of Ulugan Bay. The mixing and clustering of coastal occupancy and use, intensive paddy production, extensive swidden clearings and fallow regrowth in interior areas reflects the social signature of residents on the landscape, based on the confluence of historical conditions, changing contemporary contexts and responses to varied outcomes.

In this light, our paper offers new insights into how indigenous peoples adjust their livelihood strategies within and between people and places in dynamic, complex ways to the challenges and opportunities of agrarian change. Distancing ourselves from broader binary constructs, we focus attention on how and why resource-dependent peoples draw on social relations to adjust their livelihoods according to changing situations and circumstances that involve risk and uncertainty in resource frontiers 'going global'.

\section{REFERENCES}

Akram-Lodhi, A.H. and C. Kay, 2010a. 'Surveying the Agrarian Question (Part 1): Unearthing Foundations, Exploring Diversity'. Journal of Peasant Studies, 37 (1): 177-202.

Akram-Lodhi, A.H. and C. Kay, 2010b. 'Surveying the Agrarian Question (Part 2): Current Debates and Beyond'. Journal of Peasant Studies, 37 (2): 255-84.

Appadurai, A., 1996. Modernity at Large: Cultural Dimensions of Globalization. Minneapolis, MN: University of Minnesota Press.

Baird, I. and B. Shoemaker, 2007. 'Unsettling Experiences: Internal Resettlement and International Aid Agencies in Laos'. Development and Change, 38 (5): 865-88.

Batterbury, S., 2001. 'Landscapes of Diversity: A Local Political Ecology of Livelihood Diversification in SouthWestern Niger'. Ecumene, 8 (4): 437-64.

Berry, S., 1989. 'Social Institutions and Access to Resources'. Africa, 59 (1): 41-55.

Berry, S., 1993. No Condition is Permanent. The Social Dynamics of Agrarian Change in Sub-Saharan Africa. Madison, WI: University of Wisconsin Press.

Berry, S., 1997. 'Tomatoes, Land, and Hearsay'. World Development, 25 (8): 1225-41.

Borras, S., 2007a. “"Free Market,” Export-Led Development Strategy and its Impact on Rural Livelihoods, Poverty and Inequality: The Philippine Experience Seen from a Southeast Asian Perspective'. Review of International Political Economy, 14 (1): 143-57.

Borras, S., 2007b. ProPoor Land Reform: A Critique. Ottawa: University of Ottawa Press.

Borras, S., 2009. Competing Views and Strategies on Agrarian Reform: Volume 2 - Philippine Perspective. Quezon City: Ateneo de Manila University Press. 
Brookfield, H., 2007. 'Working with and for Plants; Indigenous Fallow Management in Perspective'. In Voices from the Forest. Integrating Indigenous Knowledge into Sustainable Upland Farming, ed. M. Cairns, 8-15. Washington, DC: Resources for the Future Press.

Bryceson, D., 1996. 'Deagrarianization and Rural Employment in Sub-Saharan Africa: A Sectoral Perspective'. World Development, 24 (1): 97-111.

Cairns, M., 2007. 'Preface'. In Voices from the Forest. Integrating Indigenous Knowledge into Sustainable Upland Farming, ed. M. Cairns, 1-4. Washington, DC: Resources for the Future Press.

Castree, N., 2008. 'Neoliberalising Nature: Processes, Effects, and Evaluations'. Environment and Planning, 40: $153-73$.

Chaiken, M., 1994. 'Economic Strategies and Success on the Philippine Frontier'. Research in Economic Anthropology, 15: 277-305.

Conelly, T., 1992. 'Agricultural Intensification in a Philippine Frontier Community: Impact on Labour Efficiency and Farm Diversity'. Human Ecology, 20: 203-23.

Conklin, H., 1957. Hanunoo Agriculture. A Report on an Integral System of Shifting Cultivation in the Philippines. Rome: Food and Agriculture Organization of the United Nations.

Cramb, R., C. Colfer, W. Dressler, P. Laungaramsri, Le Quang Trung, E. Mulyoutami, N. Peluso and R. Wadley, 2009. 'Swidden Transformations and Rural Livelihoods in Southeast Asia'. Human Ecology, 3 (37): 323-46.

de Haan, L. and A. Zoomers, 2005. 'Exploring the Frontier of Livelihoods Research'. Development and Change, 36 (1): 27-47.

De Koninck, R., 2000. 'The Theory and Practice of Frontier Development: Vietnam's Contribution'. Asia Pacific Viewpoint, 41 (1): 7-21.

Dressler, W., 2006. 'Co-Opting Conservation: Migrant Resource Control and Access to National Park Management in the Philippine Uplands'. Development and Change, 37 (2): 401-26.

Dressler, W., 2009. Old Thoughts in New Ideas: Tagbanua Forest Use and State Conservation Measures on Palawan Island, the Philippines. Quezon City: Ateneo de Manila University Press.

Dressler, W. and J. Pulhin, 2010. 'The Shifting Ground of Swidden Agriculture on Palawan Island, the Philippines'. Agriculture and Human Values, 27: 445-59.

Eder, J., 1987. On the Road to Tribal Extinction. Berkeley, CA: University of California Press.

Eder, J., 1999. A Generation Later: Household Strategies and Economic Change in the Rural Philippines. Quezon City: Ateneo de Manila University Press.

Eder, J., 2003. 'Of Fishers and Farmers: Ethnicity and Resource Use in Coastal Palawan'. Philippine Quarterly of Culture E Society, 31: 207-25.

Eder, J., 2004. 'Who are the Cuyonen? Ethnic Identity in the Modern Philippines'. Journal of Asian Studies, 63 (3): 625-47.

Eder, J., 2005. 'Coastal Resource Management and Social Differences in Philippine Fishing Communities'. Human Ecology, 33: 147-69.

Eder, J., 2006. 'Land Use and Economic Change in the Post-Frontier Upland Philippines'. Land Degradation and Development, 17: 149-58.

Eder, J., 2008. Migrants to the Coasts: Livelihood, Resource Management, and Global Change in the Philippines. Wadsworth: Cengage Learning.

Eder, J. and J. Fernandez, 1996. 'Palawan, a Last Frontier'. In Palawan at the Crossroads: Development and the Environment on a Philippine Frontier, eds J. Eder and J. Fernandez, 1-23. Quezon City: Ateneo de Manila University Press.

Ellis, F., 2000. 'A Framework for Livelihood Analysis'. In Rural Livelihoods and Diversity in Developing Countries, ed. F. Ellis, 28-51. Oxford: Oxford University Press.

Elson, R., 1997. The End of Peasantry in Southeast Asia. London: Macmillan.

Fabinyi, M., 2009. Fishing for Fairness: Poverty, Morality and Marine Resource Management in the Calamianes Islands, Philippines. Unpublished $\mathrm{PhD}$ thesis, the Australian National University.

Fox, R., 1954. Tagbanua Religion and Society. PhD dissertation, University of Chicago, Chicago, IL and the National Museum, Manila.

Gatmaytan, D., 1992. 'Land Rights and Land Tenure Situations of Indigenous Peoples in the Philippines'. Philippine Natural Resources Law Journal, 5 (1): 5-41.

Granovetter, M., 2005. 'The Impact of Social Structure on Economic Outcomes'. Journal of Economic Perspectives, 19 (1): 33-50.

Hall, D., 2009. 'The 2008 World Development Report and the Political Economy of Southeast Asian Agriculture'. Journal of Peasant Studies, 36 (3): 603-9.

Kerkvliet, B., 1974. 'Land Reform in the Philippines since the Marcos Coup'. Pacific Affairs, 47 (3): $286-304$.

Kerkvliet, B., 1977. The Huk Rebellion: A Study of Peasant Revolt in the Philippines. Quezon City: New Day Press. 


\section{Wolfram H. Dressler and Michael Fabinyi}

Kress, J., 1977. 'Contemporary and Prehistoric Subsistence Patterns on Palawan'. In Cultural Ecological Perspectives on Southeast Asia, ed. W. Wood, 29-47. Southeast Asia Series No. 41. Athens, OH: Ohio University, Centre for International Studies.

Lacuna-Richman, C., 2002. 'The Socioeconomic Significance of Subsistence Non-Wood Forest Products in Leyte, Philippines'. Environmental Conservation, 29 (2): 253-62.

Leach, M., R. Mearns and I. Scoones, 1999. 'Environmental Entitlements: Dynamic and Institutions in CommunityBased Natural Resources Management'. World Development, 27 (2): 225-47.

Lynch, O., 1982. 'Native Title, Private Right and Tribal Land Law: An Introductory Survey'. Philippine Law Journal, 57 : 268-305.

Macours, K. and J. Swinnen, 2002. 'Patterns of Agrarian Transition'. Economic Development and Cultural Change, 50 (2): 365-94.

Marche, A., 1970 [1890]. Luzon and Palawan, translated from the French by C. Ojeda and J. Castro. Manila: Filipiniana Book Guild.

McDermott, M., 2000. Boundaries and Pathways: Indigenous Identities, Ancestral Domain, and Forest Use in Palawan, the Philippines. PhD dissertation, University of California, Berkeley.

McKay, D., 2005a. 'Rethinking Locality in Ifugao: Tribes, Domains and Colonial Histories'. Philippine Studies, 53 (4): 459-89.

McKay, D., 2005b. 'Reading Remittance Landscapes: Female Migration and Agricultural Transition in the Philippines'. Danish Journal of Geography, 105 (1): 89-99.

Mertz, O., S. Leisz, A. Heinimann, K.T. Rerkasem, W. Dressler, V.C. Pham, D. Schmidt-Vogt, C. Colfer, M. Epprecht, C. Padoch and L. Potter, 2009. 'Who Counts? Demography of Swidden Cultivators in Southeast Asia'. Human Ecology, 3 (37): 281-9.

Novellino, D., 2007. 'Cycles of Politics and Cycles of Nature: Permanent Crisis in the Uplands of Palawan'. In Modern Crises and Traditional Strategies. Local Ecological Knowledge in Island Southeast Asia, ed. R. Ellen, 185-219. London: Berghahn.

Padilla, J.E., S. Mamauag, G. Braganza, N. Brucal, D. Yu and A. Morales, 2003. Sustainability Assessment of the Live Reef-Fish for Food Industry in Palawan Philippines. Quezon City: WWF-Philippines.

Padoch, C., K. Coffey, O. Mertz, S. Leisz, J. Fox and R. Wadley, 2007. 'The Demise of Swidden in Southeast Asia? Local Realities and Regional Ambiguities’. Danish Journal of Geography, 107 (1): 29-41.

Patel, R., 2006. 'International Agrarian Restructuring and the Practical Ethics of Peasant Movement Solidarity'. Journal of Asian and African Studies, 41 (1-2): 71-93.

Pulhin, J. and W. Dressler, 2009. 'People, Power and Timber: The Politics of Community-Based Forest Management'. Journal of Environmental Management, 91: 206-14.

Raintree, J. and K. Warner, 1986. 'Agroforestry Pathways for the Intensification of Shifting Cultivation'. Agroforestry Systems, 4: 39-54.

Ribot, J. and N. Peluso, 2003. 'A Theory of Access'. Rural Sociology, 68 (2): 153-81.

Rigg, J., 2005. 'Poverty and Livelihoods after Full-Time Farming: A South-East Asian View'. Asia Pacific Viewpoint, 46 (2): 173-84.

Rigg, J., 2006. 'Land, Farming, Livelihoods, and Poverty: Rethinking the Links in The Rural South'. World Development, 34 (1): 180-202.

Rivera-Guieb, R., 1999. Socioeconomic Profile and Resource Use Study of Ulugan Bay. Palawan: Tambuyog Foundation.

Russell, S., 1987. 'Middlemen and Money-Lending: Relations of Exchange in a Highland Philippine Economy'. Journal of Anthropological Research, 43 (2): 139-61.

Russell, S., 1997. 'Class Identity, Leadership Style, and Political Culture in a Tagalog Coastal Community'. Pilipinas, 28: 79-95.

Scott, G., 1979. 'Kaingin Management in the Republic of the Philippines'. Philippine Geographical Journal, 23 (2): $58-73$.

Scott, J., 1998. Seeing Like a State. New Haven, CT: Yale University Press.

Seki, K., 2004. 'Maritime Migration in the Visayas: A Case Study of the Dalaguetenon Fisherfolk in Cebu'. In Communities at the Margins: Reflection on Social, Economic and Environmental Change in the Philippines, eds H. Umehara and G. Bautista, 193-222. Quezon City: Ateneo de Manila University Press.

Sikor, T. and C. Lund, 2009. 'Access and Property to Natural Resources: A Question of Power and Authority'. Development and Change, 40 (1): 1-22.

Tomich, T.P., P. Kilby and B.F. Johnston, 1995. Transforming Agrarian Economies. Ithaca, NY: Cornell University Press.

Tsing, A.L., 1993. In the Realm of the Diamond Queen: Marginality in an Out-of-the-Way Place. Princeton, NJ: Princeton University Press. 
Tsing, A.L., 1999. 'Becoming a Tribal Elder, and Other Green Development Fantasies'. In Transforming the Indonesian Uplands, ed. T. Li, 159-202. Amsterdam: Harwood Academic Press.

Tsing, A.L., 2003. 'Cultivating the Wild: Honey-Hunting and Forest Management in Southeast Kalimantan'. In Culture and the Question of Rights: Forests, Coasts and Seas in Southeast Asia, ed. C. Zerner, 24-55. Durham, NC: Duke University Press.

Tsing, A.L., 2008. 'Contingent Commodities: Mobilizing Labour in and beyond Southeast Forests'. In Taking Southeast Asia to Market: Commodities, Nature and a Neoliberal Age, eds J. Nevins and N. Peluso, 27-43. Ithaca, NY: Cornell University Press.

Turner, S., 2007. 'Trading Old Textiles: The Selective Diversification of Highland Livelihoods in Northern Vietnam'. Human Organization, 66 (4): 389-404.

Venturello, M., 1907. 'Manners and Customs of the Tagbanuas and Other Tribes of the Island of Palawan, Philippines'. Smithsonian Miscellaneous Collections, XLVIII (Quarterly Issues) III: 514-58.

Warner, K., 1979. Walking on Two Feet: Tagbanwa Adaptation to Philippine Society. PhD dissertation, Anthropology Department, University of Hawaii.

White, B., 1989. 'Problems in the Empirical Analysis of Agrarian Differentiation'. In Agrarian Transformations, eds G. Hart, A. Turton and B. White, 15-30. Berkeley, CA: University of California Press.

World Bank, 2007. World Development Report 2008: Agriculture for Development. Washington, DC: World Bank.

Zerner, C., 2003. Culture and the Question of Rights: Forests, Coasts and Seas in Southeast Asia. Durham, NC: Duke University Press.

Zoomers, A., 2010. 'Globalization and the Foreignization of Space: Seven Processes Driving the Current Global Land Grab'. Journal of Peasant Studies, 37 (2): 429-47. 